\title{
ALIH KODE DAN CAMPUR KODE PENJUAL DAN PEMBELI DI PASAR TRADISONAL NAMLEA
}

\section{TRANSFER OF CODE AND MIXED SELLER AND BUYER CODE IN NAMLEA TRADISONAL MARKET}

\author{
Maryam Henaulua, Karim ${ }^{b}$, Risman lye ${ }^{c}$, Yulismayanti ${ }^{d}$, Taufik \\ acde Universitas Iqra Buru \\ b Institut Agama Islam Negeri Kendari \\ JIn. Prof. Bassalamah, M.Si. \\ Pos-el: rismaniye@gmail.com
}

*) Naskah diterima: 7 Februari 2020; direvisi: 17 April 2020; disetujui: 20 Mei 2020

\begin{abstract}
Abstrak
Penelitian ini bertujuan untuk mendeksripsikan alih kode, campur kode, dan faktor penyebab terjadinya campur kode penjual dan pembeli di pasar tradisional Namlea. Penelitian ini adalah penelitian deskkritif kualitatif, yakni penelitian yang dilakukan semata-mata hanya berdasarkan pada fakta yang ada atau fenomena yang secara empiris hidup pada penuturnya. Teknik pengumpulan data yang dilakukan adalah teknik pustaka, simak, dan catat. Teknik pustaka adalah teknik yang menggunakan sumber-sumber tertulis untuk menunjang data peneliti. Data yang telah diklasifikasi dianalisis secara deskriptif kualitatif. Hasil penelitian menunjukkan tiga macam alih kode penjual dan pembeli di pasar tradisional Namlea yakni: 1) Alih kode yang dilakukan penutur; 2) Alih kode dilakukan oleh mitra tutur; dan 3) Alih kode yang dituturkan oleh penutur ketiga. Kemudian faktor penyebab terjadinya campur kode adalah campur kode penyisipan kata dan campur kode penyisipan frasa.
\end{abstract}

Kata Kunci: alih kode, campur kode, pasar, Namlea

\begin{abstract}
This study aims to describe the code experts and code mix and the factors that cause the mixing of seller and buyer codes in the traditional namlea market. This research is a qualitative descriptive study, a research conducted solely based on facts or phenomena that empirically live on the speaker. Data collection techniques used were library, refer and note technique. Library technique is a technique that uses written sources to support researchers' data. The data that has been classified is analyzed descriptively qualitatively. The results showed three types of code switching of sellers and buyers in the traditional namlea market, namely: 1) Code switching by the speaker; 2) Code switching is done by the speech partner; and 3) Code switching spoken by the third speaker. then Factors that cause code mixing are mixed word insertion codes and mixed phrase insertion codes.
\end{abstract}

Keywords: code transfer, mix code, market, Namlea 


\section{PENDAHULUAN}

Fenomena bahasa dalam kehidupan masyarakat yang multilingual berkaitan dengan perihal tindak tutur. Fenomena yang dimaksud berkaitan dengan alih kode dan campur kode yang merupakan topik permasalahan dalam penelitian ini. Alih kode merupakan suatu gejala peralihan bahasa karena berubahnya situasi tutur. Terjadinya peristiwa peralihan bahasa tersebut ditentukan oleh hubungan penutur dengan mitra tutur, kehadiran pihak ketiga, topik pembicaraan serta untuk bergengsi. Dalam berinteraksi sangat ditentukan oleh hubungan sosial kita. Interaksi sosial dapat dilakukan dengan kesantunan yang berciri linguistik atau disebut dengan interaksi linguistik dan interaksi pragmatik (Rahman 2016: 168). Alih kode dilakukan dengan kesadaran penuturnya. Hal ini bisa tampak terjadi pada penjual dan pembeli yang mengalihkan bahasa Indonesia ke bahasa Buru atau sebaliknya saat proses transaksi jual beli di pasar.

Pergantian alih kode hanya akan terjadi pada seseorang yang bisa atau menguasai lebih dari dua bahasa dan bukan terjadi antar bahasa. Hymes dalam Chaer dan Agustina (2004:107-108) mengungkapkan, "Alih kode bukan hanya terjadi antarbahasa, tetapi dapat juga antar ragam-ragam atau gaya-gaya yang terdapat dalam satu bahasa". Dari pendapat tersebut, jelas bagi kita pengalihan dari satu bahasa ke bahasa yang lain dilakukan seeorang akan berkenaan dengan kehadiran orang ketiga, pengalihan dari ragam santai ke ragam resmi, berkenaan dengan berubahnya situasi santai ke situasi formal, proses pengalihan dilakukan dengan sadar, penutur tidak menguasai kode yang dipakai atau sedang mempelajari kalimat serta kode yang terucap dengan kode semula, dan sebagainya.

Seorang pembicara atau penutur sering melakukan alih kode untuk mendapatkan keuntungan atau manfaat. Dalam peme- rintahan banyak orang memanfaatkan menggunakan bahasa daerah untuk rasa kesamaan satu masyarakat tutur, dan keuntungan untuk mengharapkan bantuan dari lawan tuturnya. Lawan bicara dapat menyebabkan alih kode untuk mengimbangi kemampuan berbahasa si lawan tutur. Kehadiran orang ketiga yang tidak berlatar belakang bahasa yang sama dengan bahasa yang digunakan oleh penutur dan lawan tutur akan mengakibatkan munculnya campur kode atau alih kode. Begitu juga dengan situasi bicara dari yang formal ke informal dapat menyebabkan alih kode, topik pembicaraan dapat terjadi alih kode dari yang formal ke yang tidak formal dikarenakan bahasa pertama yang diperoleh sama. Peranan alih kode dan campur kode dalam masyarakat sangat penting, dalam hubungannya dengan pemakaian variasi bahasa oleh seseorang atau pun kelompok masyarakat, khususnya dalam pemakaian bahasa pada masyarakat yang bilingual ataupun multilingual, misalnya di pusat pernbelanjaan tradisional atau pasar (Atiek, 2015).

Sementara itu, campur kode merupakan gejala pencampuran pemakaian bahasa yang dikarenakan adanya perubahan situasi. Hal ini bisa tampak dari interaksi antara penjual dan pembeli yang dalam interaksi tersebut terdapat gejala pencampuran pemakain bahasa yang terjadi pada serpihan bahasa pertama pada bahasa kedua (misalnya bahasa Indonesia yang diselingi katakata bahasa Buru) seperti campur kode penyisipan kata, penyisipan frasa, penyisipan klausa, penyisipan ungkapan atau idiom dan penyisipan bentuk baster (gabungan pembentukan asli dan asing). Fenomena tersebut ditentukan oleh penutur dan mitra tuturnya di tempat tertentu. Campur kode ini juga dilakukan dengan kesadaran penuturnya.

Sebuah fenomena yang menarik saat ini terjadi, yaitu banyak orang melakukan per- 
gantian kode, baik alih kode maupun campur kode dalam berkomunikasi dengan orang lain. Tujuan penelitian ini untuk mendisripsikan faktor-faktor penyebab alih kode dan wujud campur kode yang terjadi di pasar tradisional Namlea.

Dari latar belakang di atas, rumusan masalah dalam penelitian ini adalah mendeskripsikan alih kode dan campur kode dan faktor penyebab terjadinya campur kode penjual dan pembeli di pasar tradisional Namlea.

\section{LANDASAN TEORI}

\section{Sosiolinguistik}

Sosiolinguistik merupakan kajian tentang bahasa yang berkaitan dengan kondisi masyarakat. Sumarsono (2011:45) mengatakan istilah sosiolinguistik terdiri atas dua kata, yaitu sosio adalah "masyarakat" dan linguistik adalah kajian bahasa. Jadi, sosiolinguistik merupakan kajian tentang bahasa yang berkaitan dengan kondisi kemasyarakatan. Sementara itu menurut Halliday (dalam Risman: 2018:9) sosiolingusitik merupakan kajian bahasa yang berkaitan dengan pertautan bahasa dengan orang-orang yang memakai bahasa itu.

Berdasarkan pendapat-pendapat di atas dapat disimpulkan bahwa sosiolinguistik adalah ilmu yang bersifat multidisipliner yang mengkaji masalah pemakaian bahasa di masyarakat yang berkaitan dengan struktur sosial, situasional, dan budaya. Bahasa dalam studi sosiolinguistik tidak dipandang sebagai struktur saja, tetapi juga dipandang sebagai sistem sosial, sistem komunikasi, dan bagian dari kebudayaaan masyarakat tertentu.

\section{Bilingualisme}

Bilingualisme dalam bahasa Indonesia disebut juga kedwibahasaan merupakan dua bahasa atau dua kode bahasa. Secara sosiolinguistik, secara umum, bilingualisme diartikan sebagai penggunaan dua bahasa oleh seorang penutur dalam pergaulannya dengan orang lain secara bergantian. (Chaer dan Agustin 2004: 56) mengemukakan bahwa bilingualisme atau kedwibahasaan berkenaan dengan pemakaian dua bahasa oleh seorang penutur dalam aktifitas seharihari.

Menggunakan dua bahasa tentunya seseorang harus menguasai kedua bahasa tersebut. Pertama, bahasa ibunya atau bahasa pertamanya (disingkat B1), dan yang kedua adalah bahasa yang lain yang menjadi bahasa keduanya (disingkat B2). Orang yang dapat menggunakan kedua bahasa itu disebut bilingual (dalam bahasa Indonesia disebut juga dwibahasawan). Sementara itu, kemampuan untuk menggunakan dua bahasa disebut bilingualitas (dalam bahasa Indonesia disebut juga kedwibahasanan). Selain bilingualisme dengan segala jabarannya ada juga istilah multibilingualisme (dalam bahasa Indonesia disebut juga keanekabahasaan), yakni keadaan digunakannya lebih dari dua bahasa oleh seseorang dalam pergaulannya dengan orang lain secara bergantian.

Bloomfield (1958:56) mengemukakan bahwa kedwibahasaan merupakan kemampuan untuk menggunakan dua bahasa yang sama baiknya oleh seorang penutur. Namun, Hauge (dalam Chaer dan Agustina 2004: 121) berpendapat bahwa ia tahu bahwa kedwibahasaan adalah dua bahasa. Jika diuraikan secara lebih umum, kedwibahasan merupakan pemakaian dua bahasa secara bergantian, baik secara produktif maupun reseptif oleh seorang individu atau masyarakat.

Kedwibahasan adalah bukan hanya milik individu, tetapi harus diperlukan sebagai milik kelompok sehingga memungkinkan adanya masyarakat kedwibahasawan. Aslinda, dkk. (2007:23) menyebutkan 
kedwibahasaan sebagai "The practice of alternately using two language", yaitu kebiasaan menggunakan dua bahasa atau lebih secara bergantian.

\section{Alih Kode}

Alih kode (code switching) adalah peristiwa peralihan dari satu kode ke kode yang lain. Misalnya, penutur menggunakan bahasa Indonesia beralih menggunakan bahasa Buru. Alih kode merupakan salah satu aspek ketergantungan bahasa (language dependencncy) dalam masyarakat multilingual.

Dalam masyarakat multilingual, sangat sulit seorang penutur mutlak hanya menggunakan satu bahasa. Dalam alih kode, masing-masing bahasa masih cenderung mempertahankan fungsi bahasa masingmasing dan setiap fungsi sesuai dengan konteksnya. Appel (dalam Iye:2018) berpendapat dengan memberikan batasan alih kode sebagai gejala peralihan pemakaian bahasa karena perubahan situasi. Beberapa faktor yang menyebabkan alih kode, yaitu.

\section{a. Penutur}

Seorang penutur kadang dengan sengaja beralih kode terhadap mitra tutur karena suatu tujuan.

b. Mitra Tutur

Mitra tutur yang latar belakang kebahasaannya sama dengan penutur biasanya beralih kode dalam wujud alih varian dan bila mitra tutur berlatar belakang kebahasaan berbeda cenderung alih kode berupa alih bahasa.

c. Hadirnya Penutur Ketiga

Untuk menetralisasi situasi dan menghormati kehadiran mitra tutur ketiga, biasanya penutur dan mitra tutur beralih kode, apalagi bila latar belakang kebahasaan mereka berbeda.

\section{d. Pokok Pembicaraan}

Pokok Pembicaraan atau topik merupakan faktor yang dominan dalam menentukan terjadinya alih kode.

Gejala peralihan pemakaian bahasa dalam suatu tindak komunikasi ditentukan oleh penutur dan mitra tutur. Tindakan komunikasi seorang dwibahasawan dalam mengalihkan pemakaian bahasa ini dilakukan dengan adanya kesadaran dari si pemakai bahasa tersebut. Dengan demikian, alih kode itu sendiri merupakan suatu gejala peralihan pemakaian bahasa yang terjadi karena berubahnya situasi. Alih kode terjadi antarbahasa dapat pula terjadi antarragam dalam satu bahasa. Berbeda halnya dengan campur kode, sebagian besar peristiwa campur kode dilakukan seseorang secara tidak sengaja atau tidak sadar (Rulyandi, dkk, 2014). Hal ini dikarenakan sikap kemultibahasaan orang tersebut yang membuat ia mencampur beberapa frasa bahasa asing ke bahasa asli atau bahasa daerah ke bahasa Indonesia. Walaupun begitu, peristiwa campur kode juga dapat dilakukan dengan sengaja, yakni karena alasan akademis dan keterbatasan istilah dalam bahasa asli dan sebagainya.

\section{Campur Kode}

Campur kode (code-mixing) terjadi apabila seorang penutur menggunakan suatu bahasa secara domain mendukung suatu tuturan disisipi dengan unsur bahasa lainnya. Hal ini biasanya berhubungan dengan karakteristik penutur, seperti latar belakang sosisal, tingkat pendidikan, dan rasa keagamaan.

Suwito (1983:78-79) menyebutkan beberapa macam campur kode yang berdasarkan unsur-unsur kebahasaan yang terlibat di dalamnya terdiri atas penyisipan unsurunsur yang berwujud kata; penyisipan unsur-unsur yang berwujud frasa; penyisipan unsur-unsur yang berwujud bentuk 
baster; penyisipan unsur-unsur yang berwujud pengulangan kata; penyisipan unsurunsur yang berwujud ungkapan atau idiom; serta penyisipan unsur-unsur yang berwujud klausa. Namun, bisa terjadi karena keterbatasan bahasa, ungkapan dalam bahasa tersebut tidak ada padanannya sehingga ada keterpaksaan menggunakan bahasa lain, walaupun hanya mendukung satu fungsi.

Gejala alih kode biasanya diikuti dengan gejala campur kode, Thelander dalam Chaer (2010:115) menjelaskan perbedaan alih kode dan campur kode, bila di dalam suatu peristiwa tutur terjadi peralihan dari satu klausa bahasa ke klausa bahasa lain, peristiwa yang terjadi adalah alih kode. Akan tetapi apabila di dalam suatu peristiwa tutur, klausa-klausa maupun frasa-frasa yang digunakan terdiri atas klausa dan frasa campuran (hybrid cllauses, hybrid phrases), dan masing-masing klausa atau frasa itu tidak lagi mendukung fungsi sendiri-sendiri, peristiwa yang terjadi adalah campur kode, bukan alih kode.

Pemilihan kode yang akan digunakan dalam berkomunikasi ditentukan oleh beberapa faktor, antara lain, interlokutor, situasi, dan tujuan komunikasi. Jadi, penggunaan dua kode atau lebih juga sangat bergantung pada beberapa faktor tersebut. Chaer dan Agustina (2004:114) menyatakan bahwa campur kode dan alih kode yang lazim terjadi dalam masyarakat yang dwibahasawan dan anekabahasawan mempunyai kesamaan yang besar sehingga sering kali sulit dibedakan. Kesamaan campur kode dan alih kode adalah digunakannya dua bahasa atau lebih, atau dua varian dari sebuah bahasa dalam satu masyarakat tutur. Di sisi lain, perbedaan campur kode dan alih kode banyak dibicarakan. Dalam campur kode, ada sebuah kode utama atau kode dasar yang digunakan dan memiliki fungsi dan keotonomiannya, sedangkan kode-kode lain yang terlibat dalam peristiwa tutur itu hanya berupa serpihan-serpihan tanpa fungsi atau keotonomian sebagai sebuah kode.

Berbeda halnya dengan alih kode, yakni dalam alih kode setiap bahasa atau ragam bahasa yang digunakan itu masih memiliki fungsi otonomi masing-masing, dilakukan dengan sadar dan sengaja dengan sebabsebab tertentu. Dengan perkataan lain, campur kode dan alih kode yang terjadi dalam suatu masyarakat dwibahasa tidak muncul begitu saja, tetapi dipicu oleh beberapa penyebab. Jika ditelusuri, penyebab terjadinya campur kode dan alih kode adalah berpangkal pada kajian sosiolinguistik, yakni pembicara atau penulis, pendengar atau pembaca, kode yang digunakan, kapan kode itu digunakan, dan tujuan pembicaraan. Hal itu sejalan dengan pernyataan Fishman (dalam Chaer dan Agustina, 2004:108) bahwa penyebab terjadinya campur kode dan alih kode adalah siapa yang berbicara, dengan bahasa apa, kepada siapa, kapan, dan dengan tujuan apa

Jadi, penutur dapat dikatakan secara tidak sadar melakukan percampuran serpihan-serpihan bahasa ke dalam bahasa asli. Dalam campur kode, penutur menyelipkan unsur-unsur bahasa lain ketika sedang memakai bahasa tertentu. Unsur-unsur tersebut dapat berupa kata, tetapi dapat juga berupa frasa atau kelompok kata. Jika berwujud kata, biasanya gejala itu disebut peminjaman. Hal yang menyulitkan timbul, ketika memakai kata-kata pinjaman, tetapi kata-kata pinjaman ini sudah tidak dirasakan sebagai kata asing melainkan dirasakan sebagai bahasa yang dipakai.

Thelander (dalam Susmita: 2015:88) membedakan alih kode dan campur kode dengan apabila dalam suatu peristiwa tutur terjadi peralihan dari satu klausa suatu bahasa ke klausa bahasa lain disebut sebagai alih kode. Namun, apabila dalam suatu 
periswa tutur klausa atau frasa yang digunakan terdiri atas kalusa atau frasa campuran (hybrid cluases/hybrid phrases) dan masing-masing klausa atau frasa itu tidak lagi mendukung fungsinya sendiri disebut sebagai campur kode.

\section{METODE PENELITIAN}

Penelitian ini adalah penelitian deskriptif kualitatif, yakni penelitian yang dilakukan semata-mata hanya berdasarkan pada fakta yang ada atau fenomena yang secara empiris hidup pada penuturnya. Pada penelitian ini, peneliti akan mendeskripsikan "Bentuk Alih Kode dan Campur Kode dalam Interaksi Penjual dan Pembeli di Pasar Tradisional Namlea. Penelitian ini dilakukan di pasar tradisional Namlea. Alasan penulis memilih pasar tradisional Namlea karena sering terjadi peralihan bahasa berupa alih kode dan campur kode pada saat transaksi jual beli antara penjual dan pembeli di pasar tradisional Namlea.

Sugiyono (2015:224) mengatakan bahwa teknik pengumpulan data merupakan langkah yang paling strategi dalam penelitian karena tujuan utama adalah mendapatkan data. Teknik pengumpulan data yang dilakukan adalah teknik pustaka, simak, dan catat. Teknik pustaka adalah teknik yang menggunakan sumber-sumber tertulis untuk menunjang data peneliti.

Teknik simak dan catat adalah peneliti sebagai instrumen kunci yang melakukan penyimakan secara cermat, terarah, dan teliti terhadap sumber data primer, yaitu alih kode dan campur kode yang digunakan oleh penjual dan pembeli dalam percakapan pada saat terjadinya proses transaksi jual beli di pasar.

Analisis deskriptif merupakan analisis yang paling mendasar untuk menggambarkan keadaan data secara umum. Analisis deskriptif adalah penelitian yang bertujuan untuk menjelaskan atau mendeskripsikan suatu keadaan, pertistiwa, objek berupa orang atau segala sesuatu yang terkait dengan variabel-variabel yang bisa dijelaskan, baik dengan angka-angka maupun dengan kata-kata.

\section{HASIL DAN PEMBAHASAN}

Faktor penyebab terjadinya alih kode yang ditemukan dalam transasksi jual beli di pasar Tradisional Namlea adalah: (1) penutur, (2) mitra tutur, dan (3) hadirnya penutur ketiga.

\section{Alih Kode}

\section{A. Alih Kode yang Dilakukan Penutur}

Seorang penutur kadang dengan sengaja beralih kode terhadap mitra tutur karena suatu tujuan. Misalnya, mengubah situasi dari resmi menjadi tidak resmi atau sebaliknya. Hal ini dijelaskan pada data dibawah ini.

\section{Data 1}

Penjual : Ade maribali tomate, tomat segarsegar ini e. (Adik mari beli tomat segar-segar ini)

Pembeli : Berapa harga tomat sekilo Ibu?

Penjual : 20 ribu dek.

Pembeli : Ibu mahal saja. (Ibu mahal sekali)

Pembeli : Mahal sa mahal, tomat ini segarsegar. (iya betul tomat ada mahal, tetapi segar-segar)

Dalam data (1) tuturan tersebut memuat alih kode yang dilakukan oleh penjual atau penutur. Alih kode dilakukan si penjual atau penutur terhadap lawan tuturnya. Kata ehe resek, dan kata na da merupakan bahasa daerah (Buru) yang berarti iya betul dan ada. Alasan si penjual menggunakan bahasa daerah dikarenakan penutur ingin mengubah situasi agar pembeli atau lawan tutur tidak canggung dengan situasi. 


\section{Data 2}

Pembeli : Tomat su layu bagini kasih mura Jua (Tomat yang layu begini maunya harganya murah)

Penjual : Seng bisa caca kita bali juga mahal sampe (Kita beli juga dia mahal)

Pembeli : Setengah kilojua (Setengah kilo ya kalau begitu).

Pada data 2 di atas terlihat campur kode yang dituturkan oleh penjual dan pembeli. Hal ini ditandai dengan kata jua (juga) yang diungkapkan oleh pembeli untuk menawar kepada penjual agar harga barang yang dijual bisa diturunkan harganya. Ungkapan jua tersebut berarti menawar dengan memakai bahasa dialek Buru untuk mengakrabkan situasi dengan penjual.

\section{Data 3}

Penjual : Bali ikan caca (Beli ikan, Ibu)

Pembeli : Fehut kah seng (Ikanya masih segar atau tidak)

Penjual : Bagus e ini saja baru datang (Bagus sekali ini saja baru diambil)

Pembeli : Barapa satu tampa (Berapa satu tempat)

Penjual : 20 Ribu caca (20 ribu, Ibu/panggilan untuk perempuan)

Pembeli : Kasih murah jua saya mau bali 2 tampa asal kas turun harga.

(Tidak bisa kurang harganya sebab saya mau beli dua tempat)

Melalui tuturan di atas terlihat campur kode yang dituturkan oleh penjual. Hal ini di tandai dengan kata fehut (segar) penutur untuk menanyakan barang yang dijual berupa ikan dengan memepertanyakaan kualitas ikan yang mau dibelinya.

\section{B. Alih Kode Dilakukan oleh Mitra Tutur}

Mitra tutur yang latar belakang kebahasaannya sama dengan penutur biasanya beralih kode dalam wujud varian dan bila mitra tutur berlatar belakang kebahasaan berbeda cenderung alih kode berupa alih bahasa.

\section{Data 4}

Pembeli : Terusan warna merah harganya berapa pak?

Penjual : 150 ribu.

Pembeli : Akeba pak mahal sekali, kepeng samo?

(Astaga Bapak, mahal sekali, tidak ada uang)

Penjual : Iya.

Dalam data (4) tuturan tersebut memuat alih kode yang dilakukan oleh mitra tutur. Pada Kata akeba (astaga) dan kata kepeng samo (tidak ada uang) merupakan bahasa daerah Buru. Alasan si pembeli atau mitra tutur menggunakan bahasa daerah Buru dikarenakan latar belakang si pembeli berasal dari daerah Buru asli.

\section{Alih Kode yang Dituturkan oleh Pe- nutur Ketiga}

Hadirnya penutur ketiga untuk menetralisasi situasi dan menghormati kehadiran mitra tutur ketiga, biasanya penutur dan mitra tutur beralih kode, apabila latar belakang kebahasaan mereka berbeda.

\section{Data 5}

Pembeli : Baras satu karung barapa?

(Beras satu karung berapa?)

Penjual 1 : Harga biasa sa (Harga Biasa Bu)

Penjual 2 : Harga utun telo geran Polimah

(Harganya 250 ribu Ibu sama juga dengan saya.

Pembeli : Seng kira harga su naik

(Saya kira harganya su naik)

Pembeli 2: Sumurah itu

Pembeli : Iyo satukarung jua (Saya beli satu karung). 
Dalam data (5) tuturan tersebut memuat alih kode yang dilakukan si penjual 2 atau penutur ketiga terhadap pembeli. kata utun telo geran polimah (350 ribu). Alasan penjual 2 atau penutur ketiga menggunakan bahasa daerah Buru dikarenakan ingin menetralisasi situasi serta ingin menyampaikan maksud kepada pembeli bahwa harga beras yang dijual masih stabil seperti sebelumnya.

\section{Data 6}

Penjual : Beli apa caca (Beli apa, Ibu/panggilan untuk perempuan)

Pembeli : Mau bali sayur (Beli sayur)

Penjual : Bali disini jua (Beli di sini saja)

Penjual 2 : Ia bali di Ibu Mina jua dagosa sa (Beli sayur di Ibu Mina soalnya sayurnya segar-segar)

Pembeli : Ia eee su cape iko popok (Ia beli saja di sini saya sudah capek keliling).

Pada data 6 di atas menunjukkan terjadinya alih kode yang dituturkan oleh pihak ketiga, yakni penjual 2 hal ini ditandai dengan kata dagosa yang berarti masih segar. Hal ini penjual 2 menawarkan kepada pembeli untuk membeli sayur temanya dengan menyampaikan bahasa daerahnya. Di samping itu juga ada campur kode yang dituturkan oleh pembeli, yakni kata iko popok yang berarti keliling.

\section{Faktor Penyebab Terjadinya Campur Kode}

Faktor penyebab terjadinya campur kode yang ditemukan dalam transasksi jual beli di pasar tradisional Namlea adalah: (1) penyisipan kata, (2) penyisipan frasa, dan (3) penyisipan klausa.

\section{A. Campur Kode Penyisipan Kata}

Kata adalah suatu unit dari suatu bahasa yang memuat arti dan terdiri atas satu atau lebih morfem serta dapat berdiri sen- diri. Kata merupakan satuan terbesar dalam morfologi dan dianggap sebagai satuan terkecil dalam sintaksis. Umumnya, kata terdiri atas satu akar kata tanpa atau dengan afiks. Perhatikan setuasi berikut.

\section{Data 7}

Penjual : Kimi, mau beli apa?

Gamdo (bagaimana) masuk lihat dulu.

Pembeli : Mau beli tas ibu.

Dalam data (7) tuturan tersebut memuat campur kode, penjual melakukan campur kode berupa penyisipan kata dari bahasa Buru ke bahasa Indonesia kepada pembeli. Pada kata kimi (kalian) dan kata gamdo (bagaimana). Penjual mencampurkan bahasa daerah Buru ke bahasa Indonesia, alasan penjual adalah ingin menghadirkan suasana keakraban terhadap pembeli

\section{Data 8}

Pembeli : Permisi, ibu ada pakeang untuk geba besar khususnya ana fina?

(Permisi, Ibu ada pakaian untuk orang dewasa perempuan)

Penjual : Iya mo ada. Mo ukurang barapa untuk ana fina to?

Pembeli : Model kaus ibu. (Model kaus Ibu) Penjual : Oke maso jua (Mari masuk ke dalam dulu)

Dalam data (8) tuturan tersebut memuat campur kode antara penjual dan pembeli berupa penyisipan kata dari bahasa Buru ke bahasa Indonesia kepada pembeli berupa kata geba (orang), kata ana fina (perempuan), dan kata pila (ukuran). Alasan penjual dan pembeli melelakukan campur kode dikarenakan kedua belah pihak ingin membangun suasana keakraban.

\section{B. Campur Kode Penyisipan Frasa}

Frasa adalah kelompok kata yang menduduki suatu fungsi di dalam kalimat. 
Adapun campur kode yang berwujud penyisipan frasa dapat diperhatikan contoh berikut!

\section{Data 9}

Penjual : Dijual baju untukgeba bagut, mari lia-liadolo.

(Dijual baju untuk orang dewasa, mari lihat-lihat dulu)

Pembeli : Sengadabaju untukgeba rana kah? (Tidak ada baju untuk anak kecil?)

Penjual : Seng ada ibu ini hanya par orang basar.

(Tidak ada Ibu, ini untuk orang dewasa saja)

Dalam data (9) tuturan tersebut memuat campur kode antara penjual dan pembeli berupa penyisipan frasa dari bahasa Buru ke bahasa Indonesia kepada pembeli. Hal itu tampak pada kata geba bagut (orang dewasa) dan kata geba rana (anak kecil). Alasan penjual dan pembeli melelakukan campur kode dikarenakan kedua belah pihak ingin membangun suasana keakraban.

\section{Data 10}

Pembeli : Ikan barapa (Ikanya berapa)

Penjual : 20 ribu satu tampa (20 ribu satu tempat)

Pembeli : Fehut kah seng (Dia masih segar kah tidak)

Penjual : Ikan fehut eee ini sa baru di ambil (Segar sekali ikanya ini saja baru diambil).

Pada data 10 di atas tergambar penyisipan frasa, yaitu ikan fehut yang berarti ikan segar. Penjual mengungkapkan frasa tersebut guna merayu pembeli untuk membeli dagangannya dan kedua untuk mengakrabkan susasana di antara keduanya.

\section{Data 11}

Pembeli : Bajunya barapa caca (harga bajunya berapa Ibu)

Penjual : 55 ribu caca. Kalau ambe 2 seratus ribu sa (55 Ribu Bu. Tetapi jika mau beli dua seratus ribu saja)

Pembeli : Sio mahal itu (Mahal ya)

Penjual : Ambil jua eeesu mura apalagi samua lebun fehut ca. (Beli saja sudah murah saya kasih apalagi semua baru)

Pada data 11 di atas terlihat penyisipan frasa yang digunakan oleh penjual kepada pembeli, yakni frasa lebun fehat yang berarti baju baru. Hal ini digunakan oleh penjual untuk merayu pembeli.

\section{PENUTUP}

Berdasarkan hasil analsisis data, penelitian ini dapat disimpulkan bahwa ada tiga macam alih kode penjual dan pembeli di pasar tradisional Namlea, yakni: 1) Alih kode yang dilakukan penutur; 2) Alih kode dilakukan oleh mitra tutur; dan 3) Alih kode yang dituturkan oleh penutur ketiga. Kemudian faktor penyebab terjadinya campur kode adalah campur kode penyisipan kata dan campur kode penyisipan frasa.

\section{DAFTAR PUSTAKA}

Atiek, Diyah. 2015. Alih Kode dan Campur Kode Antara Penjual dan Pembeli (Analisis Pembelajaran Berbahasa Melalui Studi Sosiolinguistik). Jurnal Dimensi Pendidikan dan Pembelajaran Vol. 3 No. 2.

Aslinda dkk. 2007. Pengantar Sosiolinguistik. Bandung: PT Refika Aditama.

Bloomfield, Leonard. 1958. Language. USA :Motilal Banarsidass Publishe Chaer, Abdul. 2010. Kesantunan Berbahasa. Jakarta: Rineka Cipta. 
Chaer, Abdul dan Leonie Agustina. 2004. Sosiolinguistik, Perkenalan Awal (Edisi Revisi). Jakarta: Rineka Cipta.

Iye, Risman. "Tuturan Emosi Mahasiswa

Kota Baubau dalam Ranah Demonstrasi [Emotional Speech of The Students In Baubau City In The Demonstration]." TOTOBUANG, 6 (1), 125138 (2018).

Rahman, Abd. 2016. Kesopanan Berkomunikasi dalam Aspek Konsep Wajah. Jurnal LOA (Jurnal Kebahasaan dan Kesastraan) Balai Bahasa Kalimantan Timur Vol.11 No 2.

Rulyandi dkk. 2014. Alih Kode dan Campur Kode dalam Pembelajaran Bahasa
Indonesia di SMA. Jurnal Paedagogia (Fakultas Keguruan dan Ilmu Pendidikan Universitas Sebelas Maret), Vol. 17 No. 1.

Sugiyono. 2015. Metode Penelitian Kombinasi (Mix Methods). Bandung: Alfabeta

Sumarsono. 2011. Sosiolinguistik. Yogyakarta: Pustaka Pelajar.

Susmita. 2015. Alih Kode dan Campur Kode dalam Pembelajaran Bahasa Indonesia di SMP Negeri 12 Kerinci. Jurnal Penelitian Universitas Jambi Seri Humaniora. Vol. 17, No 2.

Suwito. 1983. Pengantar Awal Sosiolinguistik Teori dan Problema. Surakarta: UNS Press. 